\title{
Influence of food composition on the biokinetics and tissue distribution of zinc and americium in mussels
}

\author{
Nicholas S. Fisher* \& Jean-Louis Teyssié \\ International Laboratory of Marine Radioactivity, Musée Océanographique, MC-98000, Monaco
}

\begin{abstract}
A series of radiotracer experiments was conducted to investigate the influence of food type on the biokinetics of zinc and americium in the common mussel Mytilus edulis. Four types of food - a diatom, a green alga, glass beads, and egg albumin particles - were labelled with gamma-emitting isotopes (either ${ }^{65} \mathrm{Zn}$ or ${ }^{241} \mathrm{Am}$ ) and fed to the mussels. The beads and albumin particles, of comparable size to the algal species, were used as representative pure mineral and pure protein particles, respectively, enabling a direct comparison of the assimilation of the 2 metals from a common source. Wet weight concentration factors of ${ }^{65} \mathrm{Zn}$ and ${ }^{241} \mathrm{Am}$ in whole mussels ranged from $\sim 12$ to 35 after $5 \mathrm{~d}$ of feeding. ${ }^{241} \mathrm{Am}$ was retained longer than ${ }^{65} \mathrm{Zn}$ by shells, while ${ }^{65} \mathrm{Zn}$ was retained much longer than ${ }^{241} \mathrm{Am}$ in the soft parts. In the soft parts, ${ }^{241} \mathrm{Am}$ was predominantly found in the digestive gland, while ${ }^{65} \mathrm{Zn}$ crossed the gut lining far more effectively than ${ }^{241} \mathrm{Am}$ and was distributed to a greater extent in the gills, muscle, mantle and foot. There was no appreciable influence of food type on the assimilability of the radiotracers, as the mussel tissues distinguished between ${ }^{65} \mathrm{Zn}$ and ${ }^{241} \mathrm{Am}$ irrespective of food. This was probably a result of the rapid desorption of these radionuclides from the food particles into the acidic gut of the animals, followed by binding of ${ }^{65} \mathrm{Zn}$ to specific ligands or molecules that introduce it into specific metabolic pathways.
\end{abstract}

\section{INTRODUCTION}

Previous studies of the trophic transfer of metals in marine food chains have demonstrated varying assimilability of metals in herbivorous animals. Some metals show virtually no assimilation in herbivores, as shown for example with the transuranic elements in marine zooplankton (Fowler 1982, Fisher et al. 1983b). Other metals, some of which are essential (e.g. Cu, Zn, $\mathrm{Mn}$ ) and some non-essential (e.g. Po), do become assimilated into animal tissue (Cherry et al. 1983). Many of these assimilable metals appear to associate with protein in the herbivore's food supply (Davies 1978, Fisher et al. 1983c), while some non-assimilable metals such as $\mathrm{Pb}, \mathrm{Am}$, and $\mathrm{Pu}$ appear to associate with mineral fractions (e.g. diatom shells) of plant cells (Schulz-Baldes \& Lewin 1976, Fisher et al., 1980, $1983 \mathrm{a}, \mathrm{c})$. The question thus arises as to the possible

\footnotetext{
- Present address: Oceanographic Sciences Division, Brookhaven National Laboratory, Upton, Long Island, New York 11973, USA
}

influence of the food supply itself, or more specifically the types of ligands in the food to which the metals are bound, on the assimilability of metals in herbivores. For example, would all metals associated with protein in the food likely show the same behavior in the animal eating this food, all metals bound to mineral fractions the same assimilability, etc? Interest in such questions stems, in part, from the possible predictive capabilities that such general trends may signify.

As a first approach to this problem, we have examined the biokinetics of 2 metals, zinc and americium, in the common mussel Mytilus edulis. This herbivorous animal is easy to handle and lends itself readily to laboratory experimentation, as numerous investigations have previously demonstrated. Our laboratory has had an ongoing research program on the food chain transfer of metals to herbivores, including $M$. edulis, and has developed a radiotracer methodology to investigate the trophic transfer of metals into this animal (Bjerregaard et al. 1985). Zinc was chosen as a representative essential metal and americium as a representative non-essential metal; 
both are particle reactive, have gamma emitting isotopes, and it is therefore relatively easy to label food particles with them and monitor their eventual fate. Initially, 2 different phytoplankters - a diatom and a green alga - were selected as food sources, each labelled with either ${ }^{65} \mathrm{Zn}$ or ${ }^{241} \mathrm{Am}$. However, owing to the uncertainty of the biochemical associations of each metal in each algal cell, subsequent experiments utilized uniform, pure mineral or protein particles as food. The biokinetics of $\mathrm{Zn}$ and $\mathrm{Am}$ in $M$. edulis were therefore compared in which the ligands themselves to which the metals were bound in the food were identical for each metal.

\section{MATERIALS AND METHODS}

Experiments utilized the common mussel Mytilus edulis obtained commercially and acclimated in the laboratory for 3 to $4 \mathrm{wk}$ in running seawater. The mussels were cleaned of epifauna and -flora immediately prior to the experiments. Their weights, which remained essentially constant during the experiments, are given in Table 1 .

In the experiments, mussels were fed 4 types of radiolabelled food: the marine centric diatom Thalassiosira pseudonana (clone $3 \mathrm{H}$ ), the marine green alga Dunaliella tertiolecta (clone Dun), acid-washed glass beads (obtained from Polysciences Inc., Warrington, Pa., USA), or chicken egg albumin particles. The glass beads were used as representative pure mineral particles while the albumin was used as pure protein particulate matter. Preliminary experiments established that all particles sorb ${ }^{65} \mathrm{Zn}$ and ${ }^{241} \mathrm{Am}$ and that all were readily filterable by $M y t i l u s$ edulis. The phytoplankton cells were from unialgal clonal cultures maintained in f/2 medium (Guillard \& Ryther 1962) minus $\mathrm{Cu}, \mathrm{Zn}$, and EDTA additions, prepared from sterile filtered (Millipore Millistak) Mediterranean surface seawater. The glass beads had comparable dimensions to the phytoplankton: 3 to $10 \mu \mathrm{m}$ diameter. The albumin particles were prepared as follows: a chicken egg was boiled for $15 \mathrm{~min}$, the albumin was placed in an electric mixer for $10 \mathrm{~min}$, the resulting particles suspended in sterile filtered seawater, and the suspension filtered through a $12 \mu \mathrm{m}$ Nuclepore polycarbonate filter. Particles that passed through the filter (i.e. $<12 \mu \mathrm{m}$ diameter) were used in the experiments.

The experiments basically followed the experimental protocol described in Bjerregaard et al. (1985). The phytoplankton, beads, and albumin were suspended in unenriched sterile filtered seawater and exposed to either ${ }^{241} \mathrm{Am}\left(359 \mathrm{kBq} \mathrm{1} \mathrm{l}^{-1}\right.$, or $\left.1.25 \times 10^{-8} \mathrm{M}\right)$ or ${ }^{65} \mathrm{Zn}$ (347 kBq l-1, or $7.34 \times 10^{-7} \mathrm{M}$ total $\mathrm{Zn}$ added) for $96 \mathrm{~h}$. The ${ }^{241} \mathrm{Am}$ and ${ }^{65} \mathrm{Zn}$ were obtained from the C.E.A., Gif-sur-Yvette, France and were dissolved in dilute $\mathrm{HNO}_{3}$ and $\mathrm{HCl}_{1}$ respectively. All particles (i.e. algal cells, beads, and albumin) accumulated the radionuclides, and were resuspended out of their radiolabelled water using $3 \mu \mathrm{m}$ Nuclepore filters ( $>93 \%$ efficiency for all particles) into unlabelled sterile filtered seawater (Bjerregaard et al, 1985). The stock suspensions of 'hot' particles in 'cold' seawater $\left(\sim 10^{6}\right.$ particles $\left.\mathrm{ml}^{-1}\right)$ were maintained in dim light and the particle density and radioactivity per particle were monitored daily (Fisher et al. 1983a). Aliquots were removed by pipet and added to polycarbonate beakers, each containing 1 mussel in $200 \mathrm{ml}$ of sterile filtered seawater.

The particle density was adjusted to $1 \times 10^{4} \mathrm{ml}^{-1}$ at the beginning of each feeding day for all particles, corresponding to a level of about $40 \mu \mathrm{g}$ dry wt. $\mathrm{d}^{-1}$ of food given to each mussel. At these food densities, radionuclide accumulation efficiency in the mussel is independent of phytoplankton cell densities (Dahlgaard 1981). At higher feeding rates $(0.6$ to $4.8 \mathrm{mg}$ musse $\mathrm{l}^{-1} \mathrm{~d}^{-1}$ ), metal accumulation efficiencies are reduced, as shown by Borchardt (1983) using ${ }^{109} \mathrm{Cd}$. Preliminary experiments with $3 \mathrm{H}$ showed that virtually all particles were filtered by the mussels within $1 \mathrm{~h}$. Fresh feeding suspensions were prepared daily over a

Table 1. Mytilus edulis. Mean wet weight $(\mathrm{g}) \pm 1 \mathrm{SD}$ of mussels and mussel tissues

\begin{tabular}{|c|c|c|c|c|c|c|c|c|c|c|c|}
\hline Food & & $n$ & $\begin{array}{l}\text { Whole } \\
\text { mussel }\end{array}$ & Shell & Soft parts & $\begin{array}{l}\text { Digestive } \\
\text { gland }\end{array}$ & Mantle & Muscle & Gills & Foot & Byssus \\
\hline 3H/Dun & Am & 10 & $15.8 \pm 1.8$ & $4.9 \pm 0.7$ & $2.2 \pm 0.7$ & $0.17 \pm 0.08$ & $0.47 \pm 0.18$ & $0.22 \pm 0.07$ & $0.44 \pm 0.10$ & $0.10 \pm 0.02$ & $0.10 \pm 0.10$ \\
\hline $5 \mathrm{~d}$ feeding & $\mathrm{Zn}$ & 10 & $14.7 \pm 1.5$ & $4.8 \pm 0.6$ & $2.0 \pm 0.7$ & $0.12 \pm 0.05$ & $0.34 \pm 0.07$ & $0.21 \pm 0.14$ & $0.35 \pm 0.12$ & $0.06 \pm 0.02$ & $0.02 \pm 0.01$ \\
\hline Beads/albumin & $A m$ & 10 & $18.2 \pm 0.3$ & $5.8 \pm 0.6$ & $3.3 \pm 0.5$ & $0.26 \pm 0.05$ & $0.70 \pm 0.13$ & $0.33 \pm 0.08$ & $0.59 \pm 0.07$ & $0.07 \pm 0.02$ & $0.15 \pm 0.15$ \\
\hline $5 \mathrm{~d}$ feeding & $\mathrm{Zn}$ & 10 & $15.2 \pm 0.3$ & $4.7 \pm 0.4$ & $2.7 \pm 0.5$ & $0.19 \pm 0.07$ & $0.56 \pm 0.13$ & $0.25 \pm 0.06$ & $0.51 \pm 0.07$ & $0.05 \pm 0.02$ & $0.15 \pm 0.11$ \\
\hline $\begin{array}{l}\text { Beads/albumin } \\
6 \mathrm{~h} \text { feeding }\end{array}$ & $\begin{array}{l}\mathrm{Am} \\
\mathrm{Zn}\end{array}$ & $\begin{array}{l}20 \\
20\end{array}$ & $\begin{array}{l}18.0 \pm 1.2 \\
15.9 \pm 2.7\end{array}$ & $\begin{array}{l}5.7 \pm 0.5 \\
4.8 \pm 0.7\end{array}$ & $\begin{array}{l}2.8 \pm 0.4 \\
2.3 \pm 0.4\end{array}$ & nd & nd & nd & nd & nd & nd \\
\hline
\end{tabular}


$5 \mathrm{~d}$ period. The mussels were maintained at $13 \pm 1{ }^{\circ} \mathrm{C}$ and their radioactivity determined after each $24 \mathrm{~h}$ feeding period. In addition, the particle density and radioactivity fractionation in the feeding suspensions were determined at the beginning of each feeding (Fisher et al. 1983a, Bjerregaard et al. 1985). The $\mathrm{pH}$ of the feeding suspensions generally declined slightly during each $24 \mathrm{~h}$ feeding, from $\sim 8.1$ to $\sim 7.9$.

Following the $5 \mathrm{~d}$ feeding, mussels were allowed to depurate in unlabelled sterile filtered seawater, maintained in polycarbonate beakers containing $600 \mathrm{ml}$, which received daily additions of $1 \times 10^{3}$ cells $\mathrm{ml}^{-1}$ of unlabelled $3 \mathrm{H}$ cells (for mussels fed radioactive $3 \mathrm{H}$, glass beads, or albumin) or of unlabelled Dun cells (for mussels fed radioactive Dun). Periodically, mussels were removed from their water, counted for their radioactivity, and placed into fresh seawater or were dissected and the radioactivity of their various tissues determined. Shells were dissected out of mussels immediately after $5 \mathrm{~d}$ feeding on labelled glass beads or albumin and were also allowed to depurate in sterile filtered seawater, their radioactivity being periodically monitored. In addition, the radioactivity of the fecal pellets produced by mussels fed radiolabelled glass beads and albumin was determined. At the end of each feeding or depuration period, fecal pellets were collected by filtering the water $(\sim 10 \mathrm{ml})$ at the bottom of each beaker containing the mussels through a $0.6 \mu \mathrm{m}$ Nuclepore filter, washing the filter with $5 \mathrm{ml}$ filtered seawater, after which its radioactivity was counted.

Another experiment, conducted only with radioactive glass beads and albumin $\left(1 \times 10^{4} \mathrm{ml}^{-1}\right)$ examined the radioactivity of whole mussels, shells, and total soft parts of 40 mussels fed over a $6 \mathrm{~h}$ period. For all experiments, the dissolved and particulate control sources of ${ }^{65} \mathrm{Zn}$ and ${ }^{241} \mathrm{Am}$ for the mussels were assessed: control beakers containing radioactive feeding suspensions but no mussels were examined simultaneously for their particle density and the radioactivity of their particles, using methods described elsewhere (Fisher et al. 1983a).

The average $\mathrm{pH}$ of the contents of the gut of bivalves is acidic, being in the range 5 to 6 (Owen 1966). To simulate the behavior of food-bound radionuclides entering the acidic gut of a bivalve, the effects of this low $\mathrm{pH}$ on the particle association of ${ }^{65} \mathrm{Zn}$ and ${ }^{241} \mathrm{Am}$ bound to the various food particles were examined. Glass beads, albumin particles, $3 \mathrm{H}$ cells, and Dun cells were labelled with ${ }^{65} \mathrm{Zn}$ and ${ }^{241} \mathrm{Am}$ as for the feeding experiments. After $112 \mathrm{~h}$ exposure to the radionuclides, the particles were resuspended out of their radioactive water into equal volumes of unlabelled, sterile filtered seawater whose $\mathrm{pH}$ was adjusted to $\mathrm{pH} 5.5$ with $\mathrm{HCl}$. The dissolved/particulate fractionation of the radionuclides was determined (Fisher et al. 1983a) over time. Checks confirmed that the $\mathrm{pH}$ of the suspensions remained constant at $5.5 \pm 0.1$

The ${ }^{241}$ Am contents of water, filter, and mussel samples were determined by counting the photon emissions from 50 to $75 \mathrm{keV}$; the ${ }^{65} \mathrm{Zn}$ was determined by counting the photon emissions from 1020 to $1220 \mathrm{keV}$. Whole mussels and mussel shells were counted with a Cosynus 60 multichannel analyzer equipped with two $7.6 \mathrm{~cm}$ well-type $\mathrm{NaI}(\mathrm{Tl})$ crystals; other samples were counted with a Packard 5650 Autogamma counter with a $1.6 \mathrm{~cm}$ well-type $\mathrm{NaI}(\mathrm{Tl})$ crystal. Appropriate standards of each isotope were counted daily, the decay of ${ }^{65} \mathrm{Zn}\left(\mathrm{t}_{1 / 2}=244 \mathrm{~d}\right)$ was corrected for, and the machines were intercalibrated daily (CV $<1 \%$ ). Generally, samples were counted for sufficient time to yield propagated counting errors $<5 \%$.

\section{RESULTS}

Microscopic counts using a hemacytometer, or particle counts using a TAII Coulter Counter, showed that all mussels ate virtually all the food provided, generally within $\sim 1 \mathrm{~h}$ of the introduction of the food. The mussels became radioactive upon feeding on radioactive food. To compare the 2 radionuclides, added in different molar concentrations, and to compare different mussels of varying weights, wet weight concentration factors (WCFs) were determined as: WCF $=$ radioactivity $\mathrm{g}^{-1}$ wet wt. whole mussel $\div$ cumulative radioactivity $\mathrm{ml}^{-1}$ in the feeding suspensions for each mussel. The WCFs of ${ }^{241} \mathrm{Am}$ and ${ }^{65} \mathrm{Zn}$ were comparable for mussels fed labelled glass beads and egg albumin, and these WCFs increased linearly over time (Fig. 1). There were no significant differences between the WCFs for ${ }^{65} \mathrm{Zn}$ among any of the 4 food types, while for ${ }^{241} \mathrm{Am}$ the WCFs seemed to plateau at $\sim 12$ by the 4 th day of feeding on phytoplankton (Fig. 1). There was no detectable loss of ${ }^{65} \mathrm{Zn}$ or ${ }^{241} \mathrm{Am}$ from the phytoplankton cells into the ambient water during the $24 \mathrm{~h}$ feeding periods. However, in the control feeding suspensions containing labelled beads and albumin, a substantial fraction of ${ }^{65} \mathrm{Zn}$ and ${ }^{241} \mathrm{Am}$ was observed to be lost to the dissolved (i.e. $<1 \mu \mathrm{m}$ ) phase in the water. A detailed analysis of this loss, over a $24 \mathrm{~h}$ period, showed that there was very rapid loss of isotope from these particles within the first $30 \mathrm{~min}$ (Fig. 2). Mussels feeding upon labelled beads or albumin particles became radioactive within the first few hours of feeding, reflecting in part the rapid filtration of food particles by the mussels (Fig. 3), but there were 2 principal source terms (dissolved and particulate) of the radionuclides during the first hour of feeding. The soft parts, whose weights are given in Table 1, had WCFs of 13 to 35 for $\mathrm{Zn}$ and 8 to 35 for Am after $6 \mathrm{~h}$ feeding 


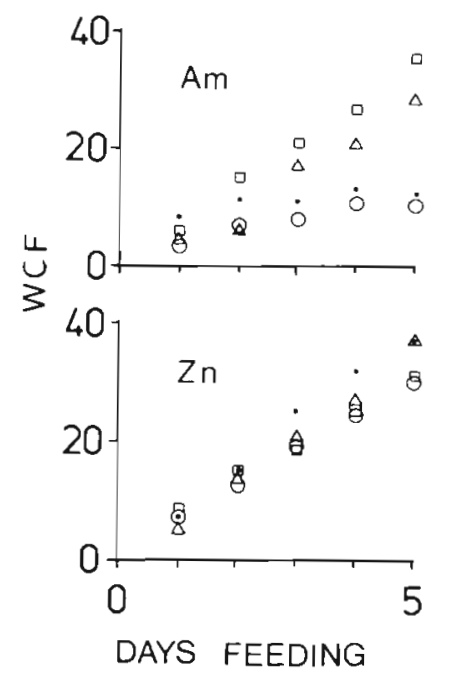

Fig. 1. Mytilus edulis. Wet weight concentration factors (WCF) of ${ }^{241} \mathrm{Am}$ and ${ }^{65} \mathrm{Zn}$ in whole mussels during $5 \mathrm{~d}$ feeding on labelled $3 \mathrm{H}$ cells $(\cdot)$, Dun cells (o), glass beads ( $\square$ ), or egg albumin particles $(\Delta)$. Data points are means of 5 replicate mussels

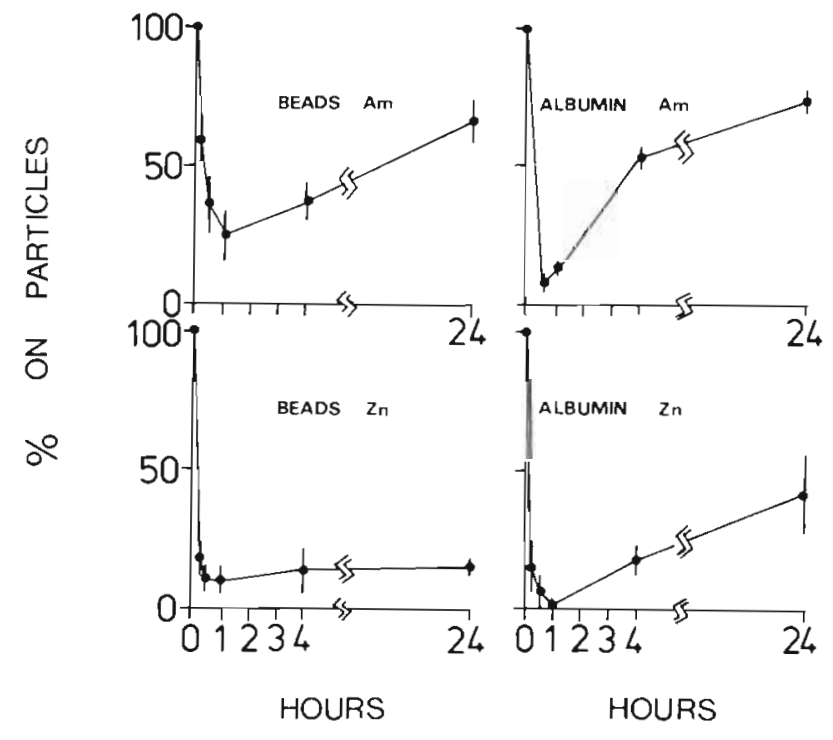

Fig. 2. Retention over $6 \mathrm{~h}$ of ${ }^{241} \mathrm{Am}$ and ${ }^{65} \mathrm{Zn}$ by glass beads or albumin particles resuspended into unlabelled sterile filtered seawater. Data points are means \pm 1 SD from 3 replicate suspensions

(Fig. 3). After $6 \mathrm{~h}$ feeding, approximately half the ${ }^{241} \mathrm{Am}$ and 60 to $75 \%$ of the ${ }^{65} \mathrm{Zn}$ in mussels fed labelled glass beads or albumin were associated with the soft parts, the remainder being found in the shell; after $5 \mathrm{~d}$ feeding there was no appreciable difference from the $6 \mathrm{~h}$ values in the nuclide fractionation in mussels for either ${ }^{65} \mathrm{Zn}$ or ${ }^{241} \mathrm{Am}$ (Fig. 4).

When placed in unlabelled seawater after $5 \mathrm{~d}$ feeding on radioactive food, the loss kinetics of the radionucldides from the whole mussels indicated mul-

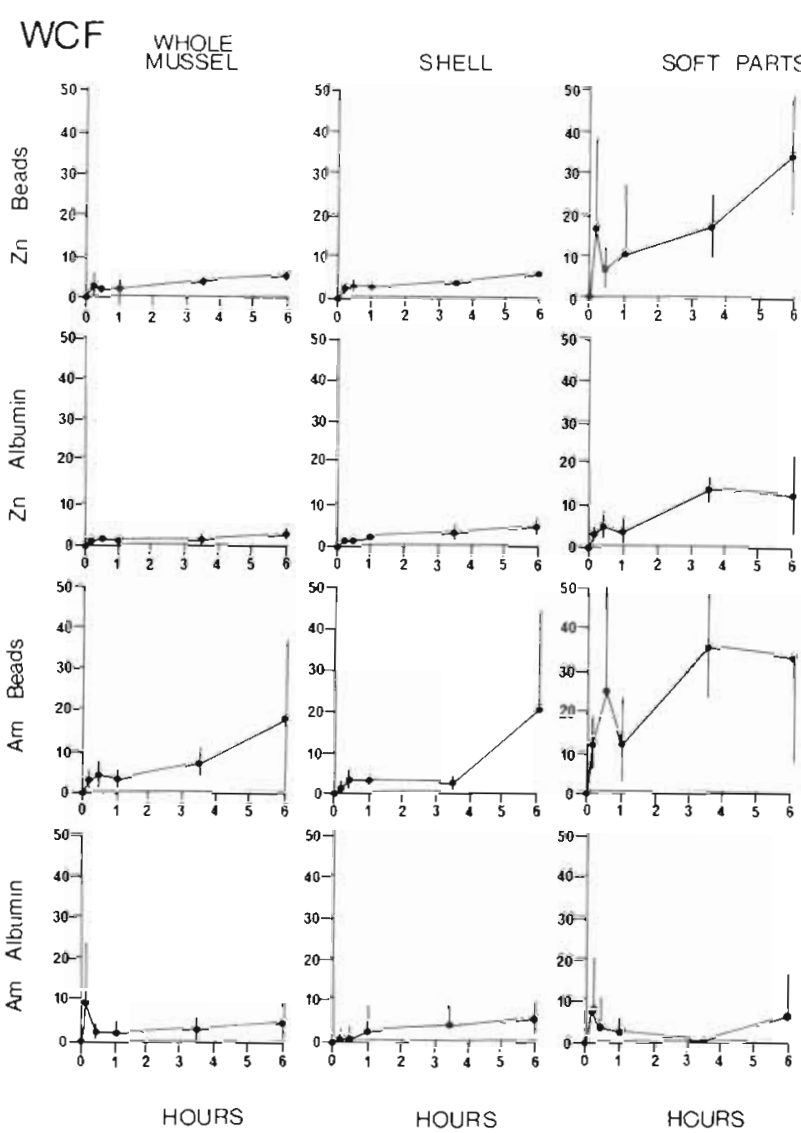

Fig. 3. Mytilus edulis. WCFs of ${ }^{65} \mathrm{Zn}$ and ${ }^{241} \mathrm{Am}$ in whole animals, shells, and soft parts of mussels during $6 \mathrm{~h}$ of feeding on labelled glass beads or albumin particles. Data points are means $\pm 1 \mathrm{SD}$ of 2 replicate mussels

ticompartmentalization of the nuclides in the animals (Fig. $5 \& 6$ ). The retention half-times $\left(\mathrm{tb}_{1 / 2}\right.$ ) of ${ }^{65} \mathrm{Zn}$ and ${ }^{241} \mathrm{Am}$ in the slowest exchanging pools of the mussels, together with the fraction of total mussel radioactivity associated with these pools, are presented in Table 2. Also shown in Table 2 are estimates of the overall tb $b_{1 / 2}$ of the ${ }^{65} \mathrm{Zn}$ and ${ }^{241} \mathrm{Am}$ in whole mussels. ${ }^{65} \mathrm{Zn}$ was retained far longer than ${ }^{241} \mathrm{Am}$ in mussels fed $3 \mathrm{H}$ or Dun cells (Fig. 5, Table 2); thus, after 42 d depuration, the mussels retained approximately $30 \%$ of their ${ }^{241} \mathrm{Am}$ and 50 to $60 \%$ of their ${ }^{65} \mathrm{Zn}$. The overall th $\mathrm{t}_{1 / 2}$ of ${ }^{65} \mathrm{Zn}$ in whole mussels fed labelled phytoplankton was approximately 4 times greater than that of ${ }^{241} \mathrm{Am}$. There were no significant differences in overall mussel retention of radionuclides between mussels fed labelled beads and labelled albumin for either nuclide or between ${ }^{65} \mathrm{Zn}$ and ${ }^{241} \mathrm{Am}$ for either food (i.e. beads or albumin) (Fig. 6). Dissection of the mussels during the depuration period showed that ${ }^{65} \mathrm{Zn}$ was retained far longer than ${ }^{241} \mathrm{Am}$ in the soft parts, irrespective of the food source (Fig. 7). In contrast, ${ }^{241} \mathrm{Am}$ was retained significantly longer than ${ }^{65} \mathrm{Zn}$ in the shells, where a 2- 

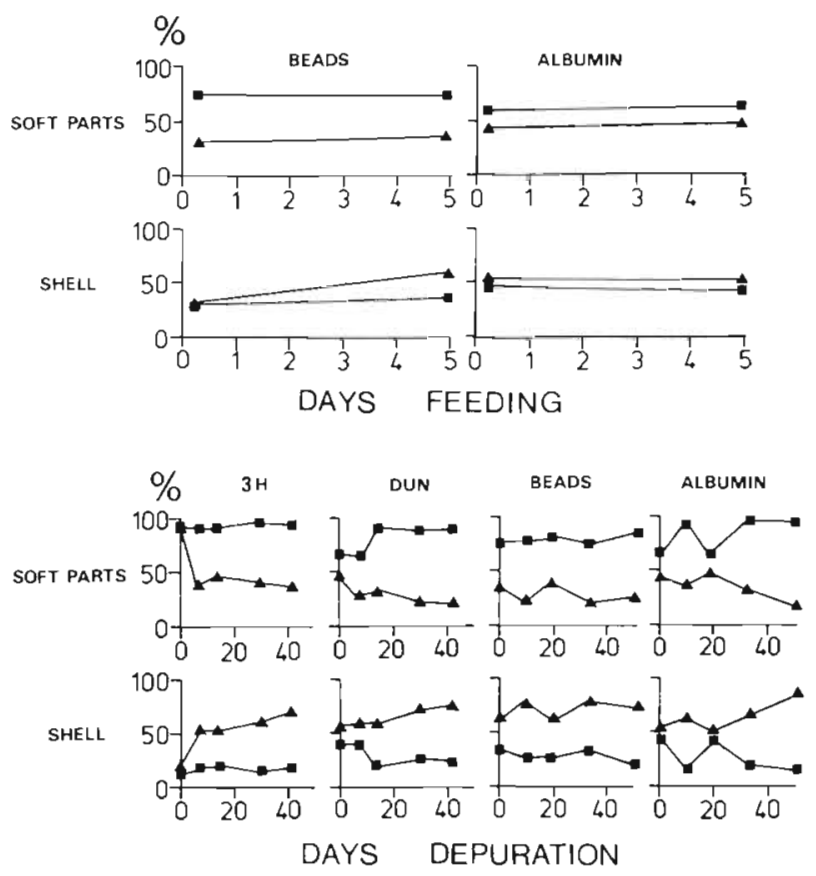

Fig. 4. Mytilus edulis. Fractionation of ${ }^{65} \mathrm{Zn}(\boldsymbol{\square})$ and ${ }^{241} \mathrm{Am}(\mathbf{4})$ in shell and soft parts of mussels fed radioactive food. Values are percentages of radioactivity measured in whole mussels found in total soft parts or shells after dissection. Fractionation of radionuclides after $6 \mathrm{~h}$ and $5 \mathrm{~d}$ feeding on labelled glass beads or albumin particles (from 2 different experiments) is shown together with fractionation in mussels fed radioactive $3 \mathrm{H}$ cells, Dun cells, glass beads, or albumin parti-

cles during 6 to 7 wk depuration in unlabelled seawater

compartment loss of radionuclide was evident (Fig. 8). The overall tb $\mathrm{t}_{1 / 2}$ of ${ }^{241} \mathrm{Am}$ in the shells was $\sim 3.5$ times that of ${ }^{65} \mathrm{Zn}$ (Table 2). These loss patterns explain the compartmentalization of ${ }^{65} \mathrm{Zn}$ and ${ }^{241} \mathrm{Am}$ in the mussel shells vs soft parts throughout the depuration period
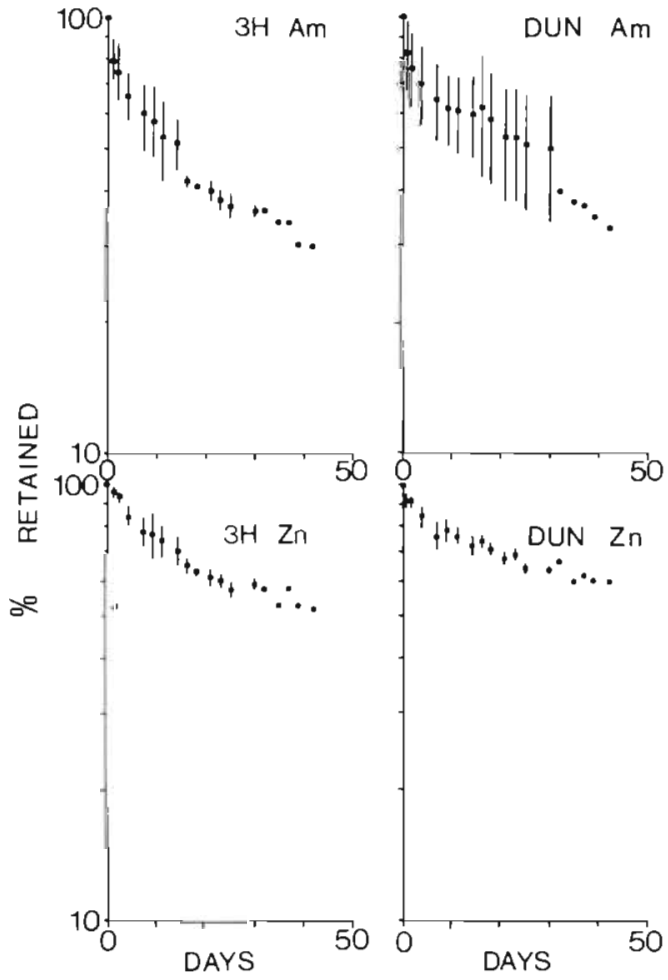

Fig. 5. Mytilus edulis. Per cent of whole mussel radioactivity retained during $6 \mathrm{wk}$ depuration in unlabelled seawater. Mussels fed for $5 \mathrm{~d}$ upon $3 \mathrm{H}$ or Dun cells labelled with either ${ }^{65} \mathrm{Zn}$ or ${ }^{241} \mathrm{Am}$. Mussels were periodically dissected, and data points represent means $\pm 1 \mathrm{SD}$ from $5 \rightarrow 1$ replicate mussels

(which was fairly uniform for all food types), with ${ }^{65} \mathrm{Zn}$ being preferentially retained in the soft parts and ${ }^{241} \mathrm{Am}$ preferentially retained in the shell (Fig. 4). The WCFs of ${ }^{65} \mathrm{Zn}$ and ${ }^{241} \mathrm{Am}$ in various mussel tissues are given in Table 3; the wet weights of the tissues are

Table 2. Mytilus edulis. Equations of radionuclide retention in the slowest exchanging pools, tb t $_{1 / 2}$ values for these pools, and estimates of overall t $b_{1 / 2}$ values. Form of equations: $y \pm a x+b$, where $y=\log$ per cent remaining in mussel or shell and $x=$ days of depuration

\begin{tabular}{|c|c|c|c|c|c|c|c|c|}
\hline \multicolumn{2}{|c|}{ Food } & $y_{\mathrm{int}}$ & Slope & $\mathrm{r}$ & $\mathrm{P}$ & $\%$ in pool & $\mathrm{tb}_{1 / 2}(\mathrm{~d})$ & Overall tb $b_{1 / 2}(\mathrm{~d})$ \\
\hline \multirow[t]{5}{*}{ Am } & Beads & 1.839 & -.0040 & -.976 & $<.01$ & 69 & 75 & $\sim 36$ \\
\hline & Albumin & 1.871 & -.0031 & -.924 & $<.01$ & 74 & 96 & $\sim 60$ \\
\hline & $3 \mathrm{H}$ & 1.694 & -.0046 & -.979 & $<.01$ & 49 & 65 & -12 \\
\hline & Dun & 1.900 & -.0086 & -.967 & $<.01$ & 79 & 35 & $\sim 22$ \\
\hline & Shell & 1.938 & -.0037 & -.996 & $<.01$ & 87 & 81 & $\sim 68$ \\
\hline \multirow{5}{*}{$\mathrm{Zn}$} & Beads & 1.820 & -.0025 & -.874 & $<.01$ & 66 & 121 & $\sim 50$ \\
\hline & Albumin & 1.922 & -.0048 & -.954 & $<.01$ & 84 & 63 & $\sim 47$ \\
\hline & $3 \mathrm{H}$ & 1.828 & -.0023 & -.816 & $<.01$ & 67 & 132 & $\sim 42$ \\
\hline & Dun & 1.876 & -.0023 & -.659 & ns & 75 & 129 & $\sim 80$ \\
\hline & Shell & 1.790 & -.0056 & -.986 & $<.01$ & 62 & 53 & $\sim 20$ \\
\hline
\end{tabular}




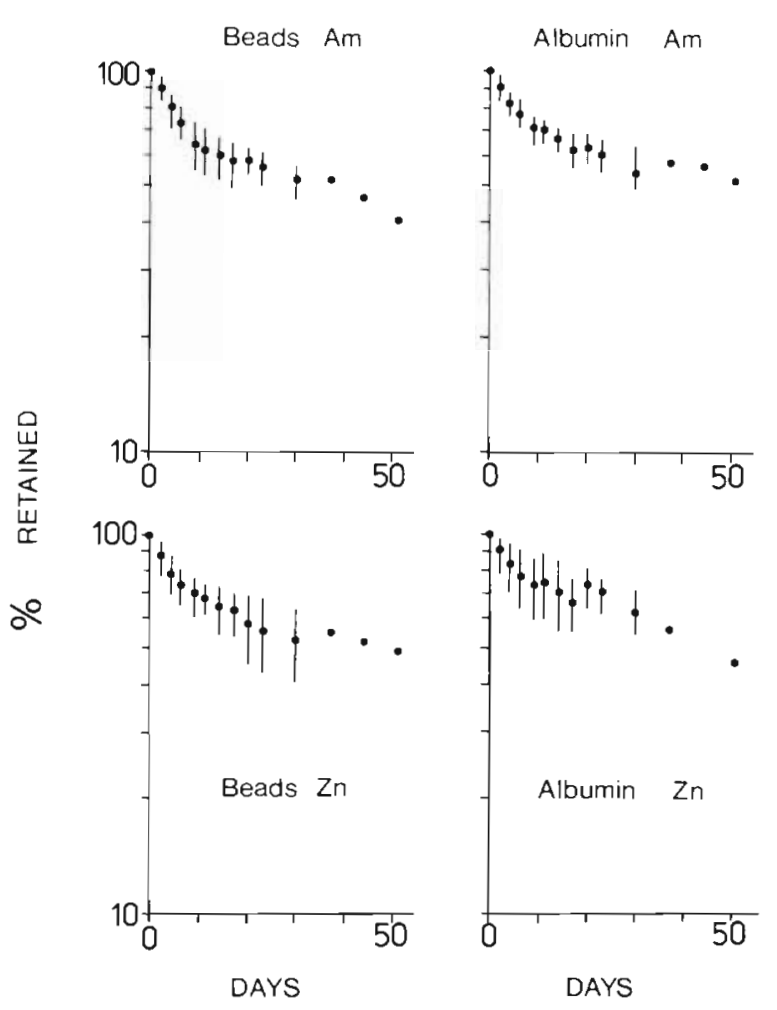

Fig. 6. Mytilus edulis. Per cent of whole mussel radioactivity retained during $7 \mathrm{wk}$ depuration in unlabelled seawater Mussels fed for $5 \mathrm{~d}$ upon glass beads or albumin particles labelled with either ${ }^{65} \mathrm{Zn}$ or ${ }^{241} \mathrm{Am}$. Mussels were periodically dissected, and data points represent means \pm 1 SD from $5 \rightarrow 1$ replicate mussels

shown in Table 1. Table 4 presents the tissue distribution of ${ }^{241} \mathrm{Am}$ and ${ }^{65} \mathrm{Zn}$ in the mussel, expressed as percentages of the total radionuclide given to each mussel during the $5 \mathrm{~d}$ feeding period. It was apparent that, irrespective of food type, the ${ }^{65} \mathrm{Zn}$ crossed the gut lining far more effectively than did ${ }^{241} \mathrm{Am}$, and was subsequently deposited to a greater extent in the other tissues (muscle, gill, mantle, foot). Thus, the ${ }^{65} \mathrm{Zn}$ WCFs in these tissues were $10^{1}$ to $10^{2}$ times higher than the ${ }^{241} \mathrm{Am}$ WCFs after $5 \mathrm{~d}$ feeding, the greatest differences generally being for mussels fed labelled algal cells (Table 3 ). In considering only radioactivity in mussel soft parts, it was clear that ${ }^{241} \mathrm{Am}$ was retained in the gut more than ${ }^{65} \mathrm{Zn}$, which showed greater penetration to such tissues as the gills and mantle (Fig. 9). Differences between the metals' tissue distributions were more pronounced in mussels fed labelled $3 \mathrm{H}$ and Dun cells than in mussels fed glass beads or egg albumin particles, where there was a significant dissolved phase source term.

Fecal pellets produced by mussels feeding on labelled beads or albumin particles were radioactive (Table 5). After $5 \mathrm{~d}$ feeding, the ${ }^{65} \mathrm{Zn}$ activity in fecal pellets fed ${ }^{65} \mathrm{Zn}$-labelled albumin particles was $\sim 3 \%$ of the
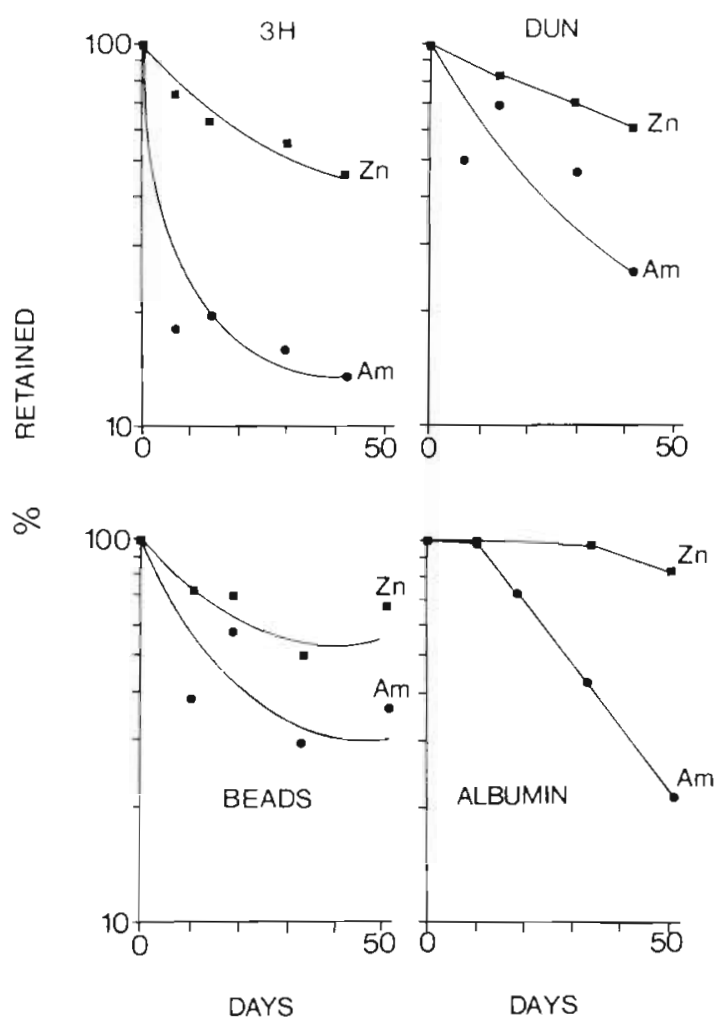

Fig. 7. Mytilus edulis. Retention of ${ }^{65} \mathrm{Zn}$ or ${ }^{241} \mathrm{Am}$ in total soft parts of mussels fed either labelled $3 \mathrm{H}$ cells, Dun cells, glass beads, or albumin particles. Different mussels were dissected during 6 to $7 \mathrm{wk}$ of depuration in unlabelled seawater and ${ }^{65} \mathrm{Zn}$ and ${ }^{241} \mathrm{Am}$ activity related to the soft parts activity of the mussels dissected at the beginning of the depuration period

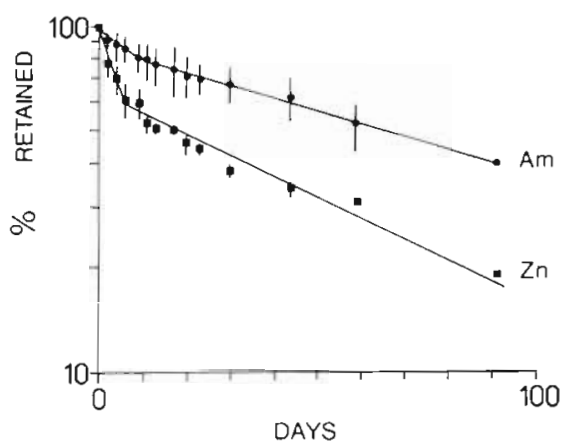

Fig. 8. Mytilus edulis. Retention of ${ }^{65} \mathrm{Zn}$ or ${ }^{241} \mathrm{Am}$ in shells dissected out of mussels after feeding for $5 \mathrm{~d}$ on labelled glass beads or albumin particles and placement into unlabelled seawater. No differences were observed between the 2 food

types; data points represent pooled data $(n=2) \pm 1$ SD

total activity presented to the mussels, in contrast to a value of $\sim 22 \%$ for ${ }^{241}$ Am-labelled albumin and $\sim 19 \%$ for ${ }^{65} \mathrm{Zn}$-labelled glass beads (Table 5). Considering also the radioactivity of fecal pellets collected from mussels during the $51 \mathrm{~d}$ depuration period, the ${ }^{65} \mathrm{Zn}$ activity content of fecal pellets represented only $\sim 6 \%$ of the total ${ }^{65} \mathrm{Zn}$ given to the mussel on labelled albu- 
Table 3. Mytilus edulis. Wet weight concentration factors of ${ }^{241} \mathrm{Am}$ and ${ }^{65} \mathrm{Zn}$ in whole mussel and mussel tissues after $0 \mathrm{~d}$ of depuration. Also shown are ${ }^{241} \mathrm{Am}$ and ${ }^{65} \mathrm{Zn}$ levels during 6 to $7 \mathrm{wk}$ of depuration in unlabelled seawater, expressed as percentages of levels at $t_{0}$ of depuration

\begin{tabular}{|c|c|c|c|c|c|c|c|c|c|c|c|c|c|c|c|c|c|c|c|}
\hline \multirow[t]{2}{*}{ Food } & \multirow[t]{2}{*}{ Days } & \multicolumn{2}{|c|}{$\begin{array}{l}\text { Whole } \\
\text { mussel }\end{array}$} & \multicolumn{2}{|c|}{ Shell } & \multicolumn{2}{|c|}{$\begin{array}{l}\text { Soft } \\
\text { parts }\end{array}$} & \multicolumn{2}{|c|}{$\begin{array}{l}\text { Digestive } \\
\text { gland }\end{array}$} & \multicolumn{2}{|c|}{ Mantle } & \multicolumn{2}{|c|}{ Muscle } & \multicolumn{2}{|c|}{ Gills } & \multicolumn{2}{|c|}{ Foot } & \multicolumn{2}{|c|}{ Byssus } \\
\hline & & Am & $\mathrm{Zn}$ & $\mathrm{Am}$ & $\mathrm{Zn}$ & $\mathrm{Am}$ & $\mathrm{Zn}$ & Am & $\mathrm{Zn}$ & Am & $\mathrm{Zn}$ & Am & $\mathrm{Zn}$ & $\mathrm{Am}$ & $\mathrm{Zn}$ & Am & $\mathrm{Zn}$ & Am & $\mathrm{Zn}$ \\
\hline $3 \mathrm{H}$ & 0 & 14 & 41 & 7 & 19 & 63 & 201 & 790 & 1289 & 4 & 219 & 24 & 212 & 3 & 149 & 1 & 133 & 189 & nd \\
\hline Dun & 0 & 10 & 38 & 10 & 48 & 14 & 200 & 194 & 1023 & 4 & 326 & 7 & 131 & 4 & 180 & 1 & 106 & nd & nd \\
\hline Beads & 0 & 29 & 25 & 59 & 25 & 59 & 99 & 369 & 417 & 22 & 83 & 52 & 46 & 15 & 101 & 7 & 58 & 1001 & 831 \\
\hline Albumin & 0 & 23 & 29 & 42 & 39 & 62 & 111 & 524 & 339 & 14 & 171 & 43 & 81 & 24 & 110 & 3 & 95 & 1115 & 1109 \\
\hline $3 \mathrm{H}$ & 7 & 43 & 68 & 157 & 74 & 43 & 150 & 29 & 175 & 400 & 299 & 17 & 65 & 200 & 307 & 200 & 110 & nd & - \\
\hline Dun & 7 & 50 & 68 & 120 & 35 & 64 & 39 & 55 & 14 & 100 & 28 & 57 & 73 & 100 & 70 & 0 & 49 & - & - \\
\hline Beads & 10 & 62 & 72 & 76 & 64 & 36 & 101 & 43 & 79 & 91 & 136 & 38 & 241 & 73 & 63 & 186 & 117 & 3 & 87 \\
\hline Albumin & 10 & 74 & 76 & 98 & 31 & 60 & 94 & 23 & 42 & 293 & 55 & 28 & 112 & 50 & 166 & 100 & 69 & 25 & 64 \\
\hline $3 \mathrm{H}$ & 14 & 36 & 68 & 114 & 79 & 30 & 56 & 31 & 157 & 50 & 42 & 8 & 25 & 367 & 123 & 300 & 68 & nd & - \\
\hline Dun & 14 & 60 & 58 & 140 & 27 & 143 & 66 & 94 & 49 & 50 & 42 & 71 & 92 & 75 & 87 & 200 & 37 & - & - \\
\hline Beads & 19 & 52 & 72 & 49 & 56 & 71 & 109 & 57 & 54 & 50 & 159 & 37 & 211 & 73 & 93 & 29 & 155 & 22 & 58 \\
\hline Albumin & 19 & 65 & 66 & 62 & 69 & 69 & 69 & 44 & 83 & 121 & 60 & 23 & 85 & 38 & 79 & 100 & 64 & 17 & 65 \\
\hline $3 \mathrm{H}$ & 30 & 29 & 59 & 100 & 63 & 16 & 135 & 11 & 76 & 75 & 105 & 25 & 94 & 67 & 470 & 300 & 165 & 2 & - \\
\hline Dun & 30 & 60 & 42 & 120 & 27 & 79 & 59 & 46 & 63 & 100 & 75 & 86 & 44 & 50 & 53 & 400 & 137 & - & - \\
\hline Beads & 33 & 55 & 48 & 63 & 48 & 36 & 49 & 13 & 28 & 14 & 34 & 29 & 120 & 33 & 38 & 57 & 116 & 13 & 32 \\
\hline Albumin & 33 & 61 & 69 & 69 & 28 & 31 & 84 & 12 & 51 & 64 & 19 & 51 & 109 & 83 & 65 & 133 & 61 & 11 & 32 \\
\hline $3 \mathrm{H}$ & 42 & 43 & 34 & 186 & 47 & 21 & 57 & 21 & 24 & 100 & 39 & 13 & 85 & 33 & 46 & 100 & 61 & 11 & - \\
\hline Dun & 42 & 40 & 45 & 80 & 23 & 36 & 51 & 22 & 43 & 50 & 26 & 29 & 82 & 25 & 68 & 100 & 59 & - & - \\
\hline Beads & 51 & 48 & 64 & 56 & 40 & 31 & 89 & 12 & 45 & 14 & 25 & 17 & 430 & 20 & 85 & 43 & 59 & 15 & 21 \\
\hline Albumin & 51 & 65 & 59 & 79 & 21 & 18 & 81 & 9 & 40 & 36 & 17 & 30 & 183 & 38 & 65 & 167 & 86 & 2 & 20 \\
\hline
\end{tabular}

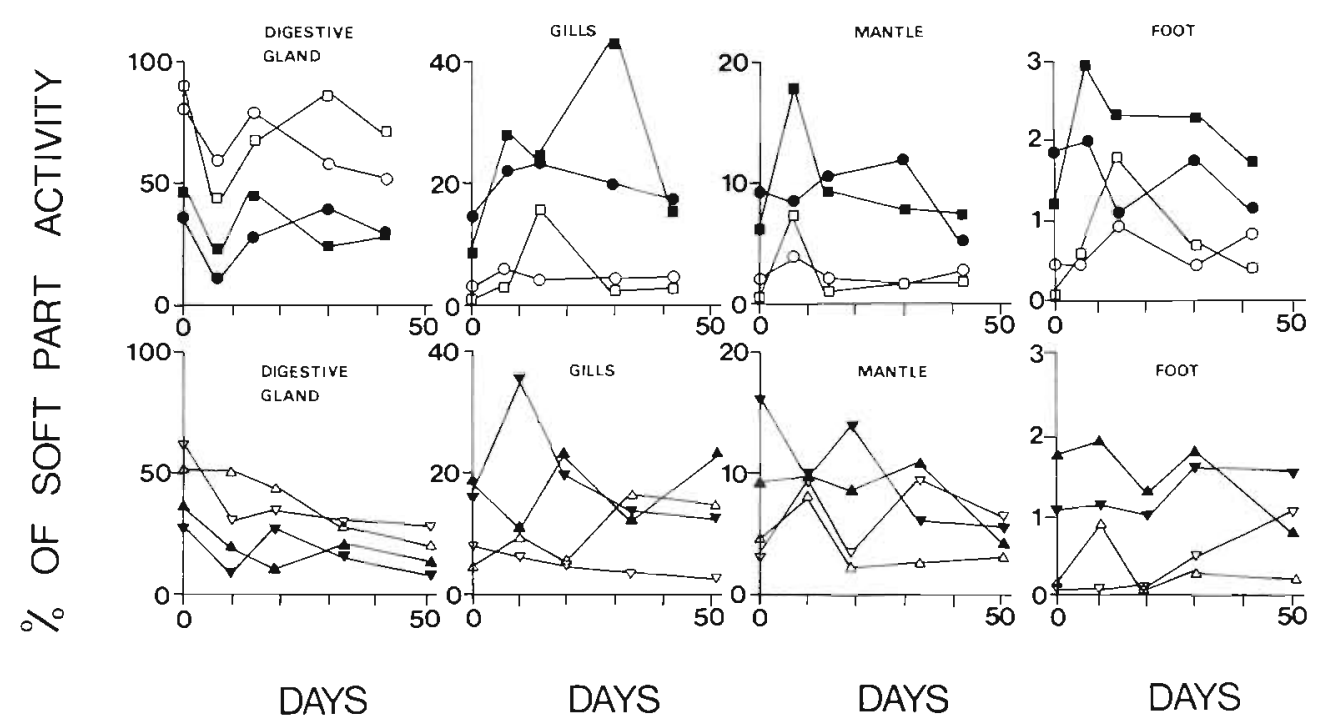

Fig. 9. Mytilus edulis. Fraction of total soft parts radioactivity found in digestive gland, gills, foot, and mantle after dissection of

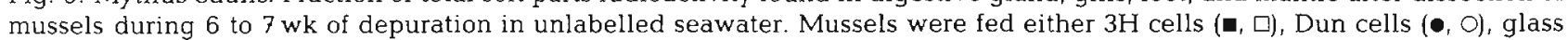
beads $(\Lambda, \Delta)$, or albumin particles $(\boldsymbol{\nabla}, \nabla)$ labelled with either ${ }^{65} \mathrm{Zn}$ (solid symbols) or ${ }^{241}$ Am (open symbols). See also Table 4

min particles during the $5 \mathrm{~d}$ feeding period, or $62 \%$ of the ${ }^{65} \mathrm{Zn}$ content lost from the mussel soft parts during the depuration period (Table 5). The fecal pellets pro- duced by mussels fed ${ }^{65} \mathrm{Zn}$-labelled glass beads contained $\sim 23 \%$ of the activity given to the mussels. All of the ${ }^{241} \mathrm{Am}$ lost from mussel soft parts was recovered 
Table 4. Mytilus edulis. Percentage of total radionuclide available during $5 \mathrm{~d}$ feeding remaining in whole mussel and mussel tissues during 6 to $7 \mathrm{wk}$ of depuration in unlabelled seawater

\begin{tabular}{|c|c|c|c|c|c|c|c|c|c|c|c|c|c|c|c|c|c|c|c|}
\hline \multirow[t]{2}{*}{ Food } & \multirow[t]{2}{*}{ Days } & \multicolumn{2}{|c|}{$\begin{array}{l}\text { Whole } \\
\text { mussel }\end{array}$} & \multicolumn{2}{|c|}{ Shell } & \multicolumn{2}{|c|}{$\begin{array}{l}\text { Soft } \\
\text { parts }\end{array}$} & \multicolumn{2}{|c|}{$\begin{array}{l}\text { Digestive } \\
\text { gland }\end{array}$} & \multicolumn{2}{|c|}{ Mantle } & \multicolumn{2}{|c|}{ Muscle } & \multicolumn{2}{|c|}{ Gills } & \multicolumn{2}{|c|}{ Foot } & \multicolumn{2}{|c|}{ Byssus } \\
\hline & & Am & $\mathrm{Zn}$ & Am & $\mathrm{Zn}$ & Am & $\mathrm{Zn}$ & Am & $\mathrm{Zn}$ & Am & $\mathrm{Zn}$ & Am & $\mathrm{Zn}$ & Am & $\mathrm{Zn}$ & Am & $\mathrm{Zn}$ & Am & $\mathrm{Zn}$ \\
\hline $3 \mathrm{H}$ & 0 & 19.0 & 58.0 & 3.4 & 9.0 & 17.1 & 52.2 & 15.2 & 25.8 & .07 & 3.3 & .49 & 5.3 & .09 & 4.6 & .01 & .67 & 0.6 & nd \\
\hline Dun & 0 & 18.7 & 53.4 & 5.8 & 19.6 & 4.7 & 35.5 & 6.5 & 13.3 & .17 & 3.5 & .23 & 3.1 & .21 & 5.2 & .02 & 64 & nd & nd \\
\hline Beads & 0 & 59.2 & 37.5 & 36.9 & 12.0 & 20.3 & 29.0 & 10.4 & 10.3 & .92 & 2.8 & 1.53 & 1.1 & .97 & 5.6 & .05 & .50 & 3.7 & 2.5 \\
\hline Albumin & 0 & 41.0 & 48.3 & 21.4 & 19.8 & 17.2 & 32.3 & 10.9 & 8.8 & .51 & 5.2 & 1.61 & 2.7 & 1.61 & 4.9 & .02 & .34 & 0.5 & 1.7 \\
\hline $3 \mathrm{H}$ & 7 & 8.4 & 42.8 & 4.9 & 7.2 & 3.1 & 39.3 & 2.1 & 9.1 & .36 & 7.5 & 12 & 0.3 & .17 & 11.9 & .02 & 1.17 & nd & 2.7 \\
\hline Dun & 7 & 8.6 & 39.9 & 5.1 & 9.5 & 2.3 & 16.0 & 1.4 & 1.7 & .10 & 1.4 & .09 & 4.1 & .14 & 3.8 & .01 & .32 & 0.4 & 1.4 \\
\hline Beads & 10 & 33.9 & 26.6 & 26.3 & 7.2 & 7.6 & 21.2 & 4.2 & 3.9 & .73 & 2.1 & .89 & 2.9 & .71 & 2.5 & .07 & .41 & 0.1 & 4.1 \\
\hline Albumin & 10 & 30.5 & 34.3 & 20.2 & 5.2 & 10.4 & 32.8 & 2.9 & 2.8 & .10 & 3.5 & .31 & 2.6 & .64 & 10.7 & .02 & .38 & 4.1 & 6.5 \\
\hline $3 \mathrm{H}$ & 14 & 7.4 & 36.9 & 3.9 & 6.6 & 3.4 & 34.4 & 2.3 & 16.2 & .03 & 3.2 & .03 & 0.4 & .52 & 8.6 & .06 & .81 & nd & 1.0 \\
\hline Dun & 14 & 9.9 & 32.1 & 5.8 & 6.7 & 3.2 & 26.7 & 2.6 & 8.5 & .06 & 3.3 & .11 & 4.0 & .14 & 7.2 & .03 & .27 & 0.1 & 2.4 \\
\hline Beads & 19 & 29.3 & 25.3 & 17.3 & 6.6 & 11.8 & 20.9 & 5.2 & 2.3 & .30 & 1.8 & .71 & 1.8 & .59 & 5.1 & .02 & .27 & 3.2 & 5.1 \\
\hline Albumin & 19 & 27.4 & 30.6 & 13.8 & 12.6 & 12.7 & 19.9 & 4.4 & 5.4 & .52 & 2.8 & .27 & 1.3 & .57 & 3.9 & .02 & .21 & 5.4 & 2.7 \\
\hline $3 \mathrm{H}$ & 30 & 6.9 & 30.0 & 4.1 & 4.7 & 2.7 & 28.7 & 2.1 & 6.8 & .04 & 2.3 & .14 & 2.6 & .07 & 12.6 & .02 & .66 & 0.1 & nd \\
\hline Dun & 30 & 9.3 & 27.3 & 6.8 & 7.0 & 2.2 & 25.2 & 1.3 & 10.3 & .04 & 3.1 & .07 & 1.1 & .08 & 5.1 & .01 & .44 & 0.4 & 1.0 \\
\hline Beads & 33 & 30.7 & 18.3 & 23.8 & 6.7 & 5.8 & 14.0 & 1.5 & 2.7 & .15 & 1.6 & .31 & 1.1 & .21 & 1.8 & .02 & .25 & 3.0 & 4.6 \\
\hline Albumin & 33 & 24.3 & 32.2 & 16.1 & 5.6 & 7.5 & 31.5 & 2.2 & 5.3 & 71 & 2.1 & .60 & 2.8 & 1.33 & 4.3 & .04 & .51 & 2.0 & 11.7 \\
\hline $3 \mathrm{H}$ & 42 & 6.8 & 25.5 & 4.7 & 4.5 & 2.3 & 23.9 & 1.7 & 7.2 & .06 & 1.7 & .10 & 5.4 & .05 & 3.5 & .01 & .41 & 0.0 & 2.2 \\
\hline Dun & 42 & 6.4 & 23.9 & 5.0 & 5.4 & 1.2 & 21.0 & 0.6 & 6.2 & .02 & 1.1 & .05 & 3.1 & .05 & 3.6 & .01 & .25 & 0.3 & 1.8 \\
\hline Beads & 51 & 26.6 & 22.3 & 19.2 & 4.2 & 7.4 & 19.5 & 1.4 & 1.7 & .20 & 0.9 & .38 & 3.5 & .20 & 4.6 & .02 & .15 & 4.2 & 3.5 \\
\hline Albumin & 51 & 26.3 & 26.5 & 22.6 & 3.9 & 3.6 & 27.0 & 1.0 & 2.3 & .22 & 1.5 & .52 & 4.1 & .56 & 3.8 & .04 & .43 & 0.7 & 10.7 \\
\hline
\end{tabular}

Table 5. Mytilus edulis. Radioactivity detected in mussel fecal pellets fed ${ }^{65} \mathrm{Zn}$ - or ${ }^{241}$ Am-labelled glass beads or albumin particles during $5 \mathrm{~d}$ feeding and $7 \mathrm{wk}$ depuration in unlabelled seawater. Values are means $\pm 1 \mathrm{SD}$ from 5 mussels. $E_{0}==$ total $\mathrm{dpm}$ recovered in fecal pellets during $5 \mathrm{~d}$ feeding; $\mathrm{G}=$ total dpm given to each mussel during $5 \mathrm{~d}$ feeding; $\mathrm{E}^{\prime}=\left(\mathrm{E}_{0} / \mathrm{G}\right) \times 100 ; \mathrm{E}_{1}$ $=$ total dpm recovered in fecal pellets during 51 d depuration; $E^{\prime \prime}=\left[\left(E_{0}+E_{1}\right) / G\right] \times 100 ; L=$ estimate of dpm lost from soft parts of each mussel during 51 d depuration; $E^{\prime \prime \prime}=\left(E_{t} / L\right) \times 100$

\begin{tabular}{|c|c|c|c|c|c|c|c|c|}
\hline \multirow[b]{2}{*}{ Food } & & \multicolumn{3}{|c|}{ Feeding } & \multicolumn{4}{|c|}{ Depuration } \\
\hline & & $E_{0}$ & $\mathrm{G}$ & $E^{\prime}$ & $E_{1}$ & $E^{\prime \prime}$ & L & $E^{\prime \prime \prime}$ \\
\hline \multirow{2}{*}{${ }^{65} \mathrm{Zn}$} & & $\begin{array}{l}5787 \\
+1450\end{array}$ & 30100 & $\begin{array}{l}19.2 \\
\pm 4.8\end{array}$ & $\begin{array}{l}1019 \\
+225\end{array}$ & $\begin{array}{l}22.6 \\
+4.9\end{array}$ & 2806 & $\begin{array}{l}36.3 \\
+80\end{array}$ \\
\hline & Albumin & $\begin{array}{c}413 \\
\pm 125\end{array}$ & 14650 & $\begin{array}{c}2.8 \\
\pm 0.9\end{array}$ & $\begin{array}{l}475 \\
\pm 11\end{array}$ & $\begin{array}{c}6.1 \\
\pm 1.0\end{array}$ & 769 & $\begin{array}{l}61.8 \\
\pm 1.4\end{array}$ \\
\hline \multirow[t]{2}{*}{${ }^{241} \mathrm{Am}$} & & $\begin{array}{l}8696 \\
\pm 2056\end{array}$ & 26413 & $\begin{array}{l}32.9 \\
\pm 7.8\end{array}$ & $\begin{array}{l}4800 \\
\pm 587\end{array}$ & $\begin{array}{l}51.1 \\
\pm 8.1\end{array}$ & 3426 & $\begin{array}{l}140.1 \\
\pm 17.1\end{array}$ \\
\hline & Albumin & $\begin{array}{l}4878 \\
\pm 770\end{array}$ & 22422 & $\begin{array}{l}21.8 \\
\pm 3.4\end{array}$ & $\begin{array}{l}3570 \\
\pm 783\end{array}$ & $\begin{array}{l}37.7 \\
\pm 4.9\end{array}$ & 3039 & $\begin{array}{l}117.5 \\
\pm 25.8\end{array}$ \\
\hline
\end{tabular}

in fecal pellets; values $>100 \%$ may indicate scavenging of dissolved ${ }^{241} \mathrm{Am}$ (lost from shells) by the deposited fecal pellets (Table 5).

The retention of ${ }^{65} \mathrm{Zn}$ and ${ }^{241} \mathrm{Am}$ by the algal cells, glass beads, and albumin particles suspended in acidic ( $\mathrm{pH}$ 5.5) unlabelled seawater is presented in Fig. 10. Within $1 \mathrm{~h},>70 \%$ of the ${ }^{65} \mathrm{Zn}$ was lost from all labelled particles. Similarly, $>70 \%$ of the ${ }^{241} \mathrm{Am}$ was lost from the $3 \mathrm{H}$ cells, glass beads, and albumin particles within $1 \mathrm{~h}$, however, the Dun cells lost only about $30 \%$ of their ${ }^{241} \mathrm{Am}$ during this time.

\section{DISCUSSION}

It was evident from the data that the biokinetics of ${ }^{65} \mathrm{Zn}$ and ${ }^{241} \mathrm{Am}$ in Mytilus edulis were little influenced by the type of food presented to the mussels. Thus, the 

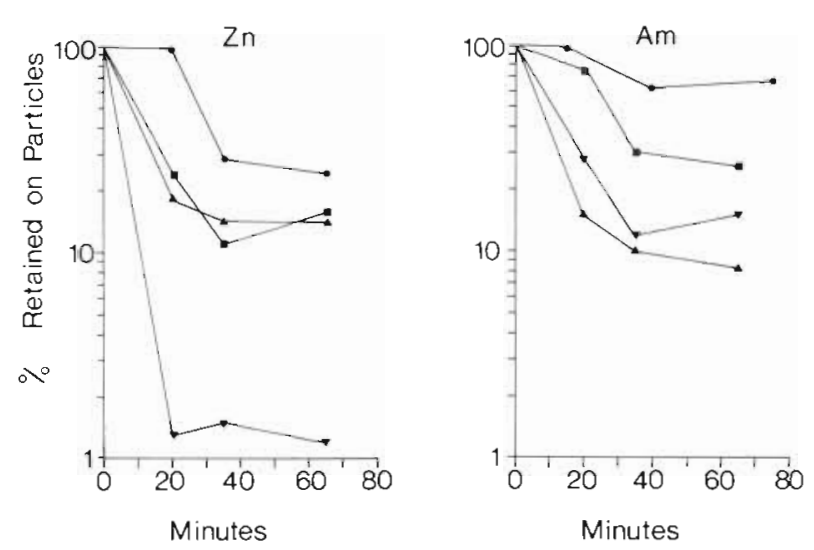

Fig. 10. Thalassiosira pseudonana, Dunaliella tertiolecta. Retention of ${ }^{65} \mathrm{Zn}$ and ${ }^{241} \mathrm{Am}$ on algal cells, glass beads, and egg albumin particles resuspended into unlabelled seawater, $\mathrm{pH}$ 5.5. 3H cells $(\boldsymbol{\square})$, Dun cells $(\bullet)$, glass beads $(\mathbf{\Lambda})$, and albumin ( $\mathbf{v})$

mussels were able to discriminate between $\mathrm{Zn}$ and Am carried on the same food source, suggesting specificity of ligands in the animal for $\mathrm{Zn}$. Partial explanation for the unimportance of food may be found in the results from the desorption experiment at $\mathrm{pH}$ 5.5. Since most of the ${ }^{65} \mathrm{Zn}$ desorbed rapidly from all food particles at this $\mathrm{pH}$, equivalent to that in a bivalve's gut (Owen 1966), the mussels should 'see' equal amounts of dissolved ${ }^{65} \mathrm{Zn}$ in their gut, regardless of food type. Similarly, most of the ${ }^{241} \mathrm{Am}$ carried by $3 \mathrm{H}$ cells, glass beads, and albumin particles desorbed rapidly in seawater at $\mathrm{pH} 5.5$; however Dun cells retained $\sim 70 \%$ of their ${ }^{241} \mathrm{Am}$ over a $1 \mathrm{~h}$ period. Thus, it may be expected that ${ }^{241} \mathrm{Am}$ would be equally available to the mussel if it was introduced via ingested $3 \mathrm{H}$ cells, beads, or albumin, while those ingested Dun cells which remain undigested may be expected to carry much of their ${ }^{241} \mathrm{Am}$ in their passage through the mussel gut. This may explain why the mussel soft parts in general and digestive gland in particular retained significantly more ${ }^{241} \mathrm{Am}$ after $5 \mathrm{~d}$ feeding on $3 \mathrm{H}$ cells than when feeding on Dun cells (Tables 3 \& 4). Presumably a greater fraction of the ${ }^{241} \mathrm{Am}$ ingested on Dun cells than on $3 \mathrm{H}$ cells was excreted in fecal pellets during the $5 \mathrm{~d}$ feeding, although direct confirmation is not possible as fecal pellets were not collected from these mussels. Since both ${ }^{241} \mathrm{Am}$ and ${ }^{65} \mathrm{Zn}$ would predominantly desorb from ingested particles in an acidic gut, the greater accumulation of ${ }^{65} \mathrm{Zn}$ than of ${ }^{241} \mathrm{Am}$ in mussel tissue is probably attributable to specificity of $\mathrm{Zn}$ binding by carrier proteins, amoebocytes, or various ligands exposed to metals in the gut. That mussels can be specific in their ability to select metals, particularly essential metals such as $Z_{n}$, is well known (George \& Pirie 1980) and hardly surprising.

While ${ }^{241} \mathrm{Am}$ was retained far more in the digestive gland, ${ }^{65} \mathrm{Zn}$ was better able to cross the gut lining and was distributed more in the various tissues of the mussel. Differences in retention efficiency in these tissues or in their WCFs for ${ }^{241} \mathrm{Am}$ and ${ }^{65} \mathrm{Zn}$ were up to 1 to 2 orders of magnitude. The distribution of $\mathrm{Zn}$ in these tissues was generally comparable to results of previous laboratory and field studies for Zn (Romeril 1971, Pentreath 1973, Van Weers 1973, Shimizu 1975, Martincic et al. 1984). Fewer studies have been conducted on the tissue distribution of ${ }^{241} \mathrm{Am}$ in mussels, but again the data of previous studies (e.g. Guary \& Fowler 1981, Bjerregaard et al. 1985) are consistent with the present findings. While a number of studies report very high concentrations of ${ }^{65} \mathrm{Zn}$ in mussel kidney (Van Weers 1973, George \& Pirie 1980, Martincic et al. 1984, Roesijadi et al. 1984), Hamilton \& Clifton (1980) could find no evidence of ${ }^{241} \mathrm{Am}$ concentration in Mytilus edulis kidney, again suggesting a different metabolic pathway for the 2 metals in these animals. George \& Pirie (1980) presented evidence that ingested $\mathrm{Zn}$ is associated with granular amoebocytes in mussels and that the kidney is the major storage organ. They noted that in the kidney, the $\mathrm{Zn}$ is stored in insoluble granules within membrane-bound vesicles, and that $\mathrm{Zn}$ is eliminated in urine (via the kidneys), fecal matter, and released amoebocytes. George \& Pirie (1980) also found that while half the $\mathrm{Zn}$ in the haemolymph was in granular amoebocytes, half was associated with a high molecular weight complex. Similarly, Romeril (1971) and Engel \& Brouwer (1984) found that Zn largely associates with metallothioneintype protein in oysters. Other transition metals may behave similarly in bivalves (Janssen \& Scholz 1979, Roesijadi et al. 1984). Simkiss et al. (1982) suggested that various types of ligands may bind metals in mussels, and these ligands may well vary among different tissues. Thus, they indicated that hydroxyl groups may be operative in the intestinal epithelium and byssal threads, metallothioneins in the gills, urates in the kidneys, and phosphates in the digestive gland.

The concentration factors determined for ${ }^{65} \mathrm{Zn}$ and ${ }^{241} \mathrm{Am}$ in whole mussels exposed for $5 \mathrm{~d}$ periods are comparable with findings from previous studies that also used relatively short exposure periods (Romeril 1971, Pentreath 1973, Van Weers 1973, Dahlgaard 1981, Bjerregaard et al. 1985). However, it may be expected that the concentration factors would simply increase linearly with time, as Schulz-Baldes (1974) demonstrated over a $6 \mathrm{wk}$ period for $\mathrm{Pb}$ accumulation in mussels. Several investigators have found, however, that the concentration factors which can be computed for field-collected mussels are significantly higher than values derived from experiments using relatively short-term exposure to radionuclides (Romeril 1971, Pentreath 1973, Van Weers 1973, Martincic et al. 1984). 
Thus, the concentration factors of ${ }^{241} \mathrm{Am}$ and ${ }^{65} \mathrm{Zn}$ in mussel soft parts reported here after $5 \mathrm{~d}$ feeding are about $10 \times$ and about $50 \times$ lower, respectively, than values which can be computed for mussels collected from the Mediterranean (Ballestra et al. 1982, Martincic et al. 1984). Several environmental factors have been identified that significantly influence mussel accumulation of metals, including temperature, salinity and dissolved organic carbon levels (Phillips 1980).

Mussels can accumulate ${ }^{65} \mathrm{Zn}$ and ${ }^{241} \mathrm{Am}$ from the dissolved state as well as from food (Pentreath 1973, Bjerregaard et al. 1985), giving rise to somewhat different tissue distributions. Uptake from water is largely a result of metal adsorption to available surfaces, generally producing higher metal concentrations associated with byssal threads and the shell. Both Am and Zn are known to associate primarily with the periostracum rather than the calcite fraction of the shell (Hamilton \& Clifton 1980, Stureson 1984). Since the glass beads and albumin particles quickly lost their radionuclides via desorption into the water of the feeding suspensions, a greater fraction of the available metal was in the dissolved state. Consequently, the ${ }^{241} \mathrm{Am}$ concentration factors were higher in shells of mussels fed these particles than in mussels fed phytoplankton; differences in shell concentration factors for ${ }^{65} \mathrm{Zn}$ among the 2 natural and 2 artificial foods were unexpectedly less evident. The degree to which the dissolved state served as a source term for these radionuclides is not clear because, even though the beads and albumin lost their ${ }^{65} \mathrm{Zn}$ and ${ }^{241} \mathrm{Am}$ rapidly (Fig. 2), the mussels should be able to filter virtually all food particles very rapidly as well, thus possibly ingesting the radionuclide before it desorbed into the water. Mytilus edulis filtration rates with comparable food (diatom) particle densities $\left(1.5 \times 10^{4}\right.$ Phaeodactylum tricornutum cells $\mathrm{ml}^{-1}$, or $180 \mu \mathrm{g}$ organic dry wt. $\mathrm{l}^{-1}$ ) are around $40 \mathrm{ml}$ $\min ^{-1}$ (Riisgard \& Mohlenberg 1979), suggesting that within about 5 min all of the food particles should have been ingested by the mussels in our experiments. The rapid loss, by desorption, of radionuclides from the beads and albumin followed by subsequent increases in particulate $(>1 \mu \mathrm{m}){ }^{241} \mathrm{Am}$ and ${ }^{65} \mathrm{Zn}$ (beads excepted) remains unexplained. One possibility, as yet untested, is that the desorbed metal associates with small colloidal material which slowly adheres to the beads or albumin particles.

The overall biological half-life of ${ }^{65} \mathrm{Zn}$ in whole mussels fed labelled phytoplankton was approximately 4 times greater than that of ${ }^{241} \mathrm{Am}$, while the half-life of ${ }^{241} \mathrm{Am}$ was 3 to 4 times that of ${ }^{65} \mathrm{Zn}$ in shell. This would account for the very different fractionation of ${ }^{241} \mathrm{Am}$ and ${ }^{65} \mathrm{Zn}$ between soft parts and shell (Fig. 4). Even after 1 yr of depuration following ingestion of ${ }^{65} \mathrm{Zn}$ labelled diatoms, 50 to $80 \%$ of the total ${ }^{65} \mathrm{Zn}$ body burden remaining in mussels was found in the soft parts (Dahlgaard 1981). Half-lives of $\mathrm{Zn}$ in mussels are known to increase with exposure time because a greater fraction of the total burden of $\mathrm{Zn}$ becomes associated with the slowly exchanging pools (Van Weers 1973). A half-life of $\sim 76 \mathrm{~d}$ (after correction for radioactive decay) was calculated for ${ }^{65} \mathrm{Zn}$ in mussels contaminated at the mouth of the Columbia River and transplanted to cleaner waters off San Diego; after $1 \mathrm{yr},>$ $97 \%$ of the ${ }^{65} \mathrm{Zn}$ in the soft parts was lost (Young \& Folsom 1967). Clifton et al. (1983) have measured the $\mathrm{tb}_{1 / 2}$ of ${ }^{241} \mathrm{Am}$ in the soft parts of chronically exposed mussels to be around $300 \mathrm{~d}$, considerably longer than was apparent from our experiments. Guary \& Fowler (1981) measured ${ }^{241} \mathrm{Am}$ retention in mussels, initially labelled for $28 \mathrm{~d}$ in 'cotton-filtered' seawater, during depuration in plastic cages placed into the Mediterranean. They found a 3-compartment loss curve, with around $20 \%$ of the ${ }^{241} \mathrm{Am}$ in the slowly exchanging pool $\left(\mathrm{tb}_{1 / 2}=480 \mathrm{~d}\right)$ and around $40 \%$ of the ${ }^{241} \mathrm{Am}$ in each of 2 other pools $\left(\mathrm{tb}_{\frac{1 / 2}{2}}=11 \mathrm{~d} ; 22 \mathrm{~d}\right)$, yielding an overall t $b_{1 / 2}$ of about $30 \mathrm{~d}$, within the range of values (12 to $60 \mathrm{~d}$ ) estimated from our experiments using shorter exposure and depuration periods. Guary \& Fowler (1981) also noted that muscle and mantle tissue retained ${ }^{241} \mathrm{Am}$ most effectively, with comparatively rapid loss from shell, byssus, viscera, and gills. Analogous to the environmental influences on metal accumulation, Dahlgaard (1981) found substantial seasonal effects on ${ }^{65} \mathrm{Zn}$ depuration from Mytilus edulis, with loss rates increasing with water temperature. Half-lives of ${ }^{65} \mathrm{Zn}$ have been estimated in individual mussel tissues, with values ranging from around 4 to $8 \mathrm{~d}$ in the gills and digestive gland to about $21 \mathrm{~d}$ in muscle tissue (Pentreath 1973, George \& Pirie 1980). Simkiss \& Mason (1984) argue that the metals are retained by a variety of ligands in an animal and that it is the turnover rate and availability of specific ligands which ultimately determine the metal turnover time in an animal.

It thus appears that the quality of the food itself may have little impact on the accumulation, assimilation, tissue distribution, and retention of radionuclides in mussels. Of greater significance may be the quantity of food in waters with high particulate loads (with assimilation efficiency decreasing as the number of food particles increase above a threshold), the biological usefulness of the particular metals, and the environmental and biological factors which affect the ligand turnover within the mussels.

Acknowledgements. The International Laboratory of Marine Radioactivity operates under a tripartite agreement between the International Atomic Energy Agency, the Government of the Principality of Monaco and the Oceanographic Institute at Monaco. 


\section{LITERATURE CITED}

Ballestra, S., Thein, M., Fukai, R. (1982). Distribution of transuranic nuclides in the coastal ecosystems of the northwestern Mediterranean. VI J. Etud. Poll.: 47-52

Bjerregaard, P., Topçuoğlu, S., Fisher, N. S., Fowler, S. W. (1985). Biokinetics of americium and plutonium in the mussel Mytilus edulis. Mar Ecol. Prog. Ser 21: 99-111

Borchardt, T. (1983). Influence of food quantity on the kinetics of cadmium uptake and loss via food and seawater in Mytilus edulis. Mar. Biol. 76: 67-76

Cherry, R. D., Heyraud, M., Higgo, J. J. W. (1983). Polonium210: its relative enrichment in the hepatopancreas of marine invertebrates. Mar. Ecol. Prog. Ser. 13: 229-236

Clifton, R. J., Stevens, H. E., Hamilton, E. I. (1983). Concentration and depuration of some radionuclides present in a chronically exposed population of mussels (Mytilus edulis). Mar. Ecol. Prog. Ser. 11: 245-256

Dahlgaard, H. (1981). Bioindicators for monitoring radioactive pollution of the marine environment. RISO Rept. No. 443, Riso National Laboratory, Roskilde, Denmark

Davies, A. G. (1978). Pollution studies with marine plankton. Part II. Heavy metals. Adv. mar. Biol. 15: 381-508

Engel, D. W., Brouwer, M. (1984). Trace metal-binding proteins in marine molluscs and crustaceans. Mar. Environ. Res. 13: 177-194

Fisher, N. S., Olson, B. L., Bowen, V. T. (1980). Plutonium uptake by marine phytoplankton in culture. Limnol. Oceanogr. 25: 823-839

Fisher, N. S., Bjerregaard, P., Fowler, S. W. (1983a). Interactions of marine plankton with transuranic elements. 1. Biokinetics of neptunium, plutonium, americium, and californium in phytoplankton. Limnol. Oceanogr. 28: $432-447$

Fisher, N. S., Bjerregaard, P., Fowler, S. W. (1983b). Interactions of marine plankton with transuranic elements. 3. Biokinetics of americium in euphausiids. Mar. Biol. 75: 261-268

Fisher, N. S., Burns, K. A., Cherry, R. D., Heyraud, M. (1983c). Accumulation and cellular distribution of ${ }^{241} \mathrm{Am},{ }^{210} \mathrm{Po}$, and ${ }^{210} \mathrm{~Pb}$ in two marine algae. Mar. Ecol. Prog. Ser. 11: 233-237

Fowler, S. W. (1982). Biological transfer and transport processes. In: Kullenberg, G. (ed.) Pollutant transfer and transport in the sea, Vol. 2. CRC Press, Boca Raton, Florida, p. $1-65$

George, S. G., Pirie, B. S. J. (1980). Metabolism of zinc in the mussel, Mytilus edulis (L.): a combined ultrastructural and biochemical study. J. mar. biol. Ass. U.K. 60: 575-590

Guary, J. C., Fowler, S. W. (1981). Americium-241 and plutonium-237 turnover in mussels (Mytilus galloprovincialis) living in field enclosures. Estuar. coast. Shelf Sci. 12: $193-203$

Guillard, R. R. L., Ryther, J. H. (1962). Studies of marine planktonic diatoms I. Cyclotella nana Hustedt, and Detonula confervacea (Cleve) Gran. Can. J. Microbiol. 8: 229-239
Hamilton, E. I., Clifton, R. J. (1980). Concentration and distribution of the transuranium nuclides ${ }^{239+240} \mathrm{Pu},{ }^{238} \mathrm{Pu}$ and ${ }^{241} \mathrm{Am}$ in Mytilus edulis, Fucus vesiculosus and surface sediment of Esk estuary. Mar. Ecol. Prog. Ser. 3: 267-277

Janssen, H. H., Scholz, N. (1979). Uptake and cellular distribution of cadmium in Mytilus edulis. Mar. Biol. 55: 133-141

Martincic, D., Nurnberg, H. W., Stroeppler, M., Branica, M. (1984). Bioaccumulation of heavy metals by bivalves from Lim Fjord (North Adriatic Sea). Mar. Biol. 81: 177-188

Owen, G. (1966). Digestion. In: Wilbur, K. M., Yonge, C. M. (ed.) Physiology of Mollusca, Vol. 2. Academic Press, New York, p. 53-96

Pentreath, R. J. (1973). The accumulation from water of ${ }^{65} \mathrm{Zn}$, ${ }^{54} \mathrm{Mn},{ }^{58} \mathrm{Co}$ and ${ }^{59} \mathrm{Fe}$ by the mussel, Mytilus edulis. J. mar. biol. Ass. U.K. 53: 127-143

Phillips, D. J. H. (1980). Quantitative aquatic biological indicators. Appl. Science Publ., London

Riisgard, H. U., Mohlenberg, F. (1979). An improved automatic recording apparatus for determining the filtration rate of Mytilus edulis as a function of size and algal concentration. Mar. Biol. 52: 61-67

Roesijadi, G., Young, J. S., Drum, A. S., Gurtisen, J. M. (1984). Behavior of trace metals in Mytilus edulis during a reciprocal transplant field experiment. Mar. Ecol. Prog. Ser. 18: $155-170$

Romeril, M. G. (1971). The uptake and distribution of ${ }^{65} \mathrm{Zn}$ in oysters. Mar. Biol. 9: 347-354

Schulz-Baldes, M. (1974). Lead uptake from sea water and food, and lead loss in the common mussel Mytilus edulis. Mar. Biol. 25: 177-193

Schulz-Baldes, M., Lewin, R. A. (1976). Lead uptake in two marine phytoplankton organisms. Biol. Bull. mar. biol. Lab., Woods Hole 150: 118-127

Shimizu, M. (1975). Procedures for radioecological studies with molluscs. In: Design of radiotracer experiments in marine biological systems. International Atomic Energy Agency Tech. Rept. No. 167, Vienna, p. 121-136

Simkiss, K., Mason, A. Z. (1984). Cellular response of molluscan tissues to environmental metals. Mar. Environ. Res. 14: 103-118

Simkiss, K., Taylor, M., Mason, A. Z. (1982). Metal detoxification and bioaccumulation in molluscs. Mar. Biol. Lett. 3: 187-201

Stureson, U. (1984). In situ studies of copper and zinc enrichment in shell and soft tissue of Mytilus edulis. In: Persoone, G., Jaspers, E., Claus, C. (ed.) Ecotoxicological testing for the marine environment, Vol. 2. State Univ. Ghent and Inst. Mar. Scient. Res., Bredene, Belgium, p. 511-533

Van Weers, A. W. (1973). Uptake and loss of ${ }^{65} \mathrm{Zn}$ and ${ }^{60} \mathrm{Co}$ by the mussel Mytilus edulis L. In: Radioactive contamination of the marine environment. International Atomic Energy Agency, Vienna, p. 385-401

Young, D. R., Folsom, T. R. (1967). Loss of ${ }^{65} \mathrm{Zn}$ from the California sea-mussel Mytilus californianus. Biol. Bull. mar. biol. Lab., Woods Hole 133: 438-447 